\title{
ANALISIS KEBIJAKAN PEMANFAATAN DANA KAPITASI JKN PADA FKTP PUSKESMAS DI KABUPATEN BOGOR TAHUN 2016
}

\author{
POLICY ANALYSIS OF USED CAPITAL FUND OF JKN INPRIMARY HEALTHCARE IN BOGOR \\ IN 2016
}

\author{
Abdul Gani Hasan ${ }^{1^{*}}$, Wiku B.B. Adisasmito ${ }^{2}$ \\ ${ }^{1}$ Fakultas Kesehatan Masyarakat, Universitas Indonesiam, Depok \\ ${ }^{2}$ Departemen Administrasi dan Kebijakan Kesehatan, Fakultas Kesehatan Masyarakat Universitas \\ Indonesia, Depok
}

\begin{abstract}
Background: The purpose of analyzing the policy of utilization of JKN capitation fund at FKTP Puskesmas in Bogor Regency refers to Permenkes 21 year 2016. Method: Qualitative with Rapid Assessment Procedure, in-depth interview on 12 informant, purposive sample, related to research objectives. Results: There is a high disparity of capitation funds for puskesmas covering participants, capitation norms, number of doctors and the ratio of doctors between various puskesmas. In-depth interviews found the difficulty of fulfilling the ideal physician ratio, low capitation norms indicated the low quality of the puskesmas, not all the puskesmas did the proper planning process, the small capitation clinics were difficult in the operational and the overwhelming operational and potentially piled up, Drug fulfillment is constrained by procurement, the potential for overlapping capitation with BOK and the quality of physician services decreases in the ratio of physicians per large participant. Conclusions and suggestions: The ratio of physicians to participants is still below the standard of 1: 5000 participants need equalization effort, $60 \%$ capitation portion for services and $40 \%$ other opersional, different sufficiency there should be operational fund backups for the less, the disincentives of service need to be reviewed, Capitation of $40 \%$ portion can be complementary with BOK, the rest of the budget is advantageous if the activity alternative can be effectively efficient according to society requirement, need improvement of drug procurement mechanism, budget flexibility need to be pushed PPK-BLUD at puskesmas.
\end{abstract}

Keywords: capitation; FKTP; Puskesmas

\section{Abstrak}

Latar Belakang: Tujuan menganalisis kebijakan pemanfaatan dana kapitasi JKN pada FKTP Puskesmas di Kabupaten Bogor mengacu Permenkes 21 tahun 2016. Metode : Kualitatif dengan Rapid Assesment Procedure, wawancara mendalam pada 12 informan, sampel purposive, terkait tujuan penelitian. Hasil Terdapat disparitas tinggi dana kapitasi puskesmas meliputi peserta, norma kapitasi, jumlah dokter dan rasio dokter antara berbagai puskesmas. Wawancara mendalam didapatkan sulitnya pemenuhan rasio dokter ideal, norma kapitasi rendah menunjukkan kuantitas kualitas puskesmas rendah, belum semua puskesmas melakukan proses perencanaan dengan benar, puskesmas kapitasi kecil sulit dalam operasional dan yang besar berlebih operasional dan berpotensi menumpuk, penentuan poin cukup jauh berbeda antar tenaga, pemenuhan obat-obatan terkendala oleh pengadaan, potensi overlapping kapitasi dengan BOK dan kualitas pelayanan dokter menurun pada rasio dokter per peserta besar. Kesimpulan dan saran : Rasio dokter dengan peserta masih dibawah standar 1:5000 peserta perlu upaya pemerataan, porsi kapitasi $60 \%$ untuk Jasa dan $40 \%$ opersional lain, ketercukupannya berbeda perlu ada backup dana operasional untuk yang kurang, adanya disinsentif jasa pelayanan perlu dikaji ulang, kapitasi porsi $40 \%$ dapat komplementer dengan BOK, sisa anggaran menguntungkan bila alternatif kegiatan mampu efektif efisien sesuai kebutuhan masyarakat, perlu perbaikan mekanisme pengadaan obat, dalam fleksibilitas anggaran perlu didorong PPKBLUD pada puskesmas.

Kata kunci : kapitasi; FKTP; Puskesmas

\section{Pendahuluan}

Jaminan kesehatan menurut laporan Badan Kesehatan Dunia (WHO) tahun 2010, bertujuan untuk memastikan semua orang mendapatkan akses ke layanan kesehatan yang dibutuhkan (upaya promotif, preventif, kuratif dan rehabilitatif) dengan kualitas yang baik dan efektif dan untuk memastikan bahwa seluruh layanan kesehatan dapat mencakup orang-orang yang kesulitan secara finansial (Kutzin, 2013).

Di Indonesia, dana kapitasi untuk pembayara layanan kesehatan diperoleh dari premi peserta JKN yang sebagian cara pembayaran layanan kesehatannya melalui kapitasi. Sistem Kesehatan Nasional Indonesia memang menyebutkan bahwa upaya kesehatan perorangan pembayarannnya bersifat privat, kecuali masyarakat miskin dibayar pemerintah. (Kemenkes, 2009).

Salah satu sarana kesehatan yang dapat dibayar dengan sistem kapitasi adalah FKTP Puskesmas. Kebijakan yang mendasari pemanfaatan dana kapitasi JKN pada FKTP Puskesmas yang bukan BLUD, diterapkan melalui Peraturan Menteri Kesehatan nomor 21 tahun 2016. Kebijakan penganggaran dalam dokumen anggaran 
menggunakan Permendagri nomor 13 tahun 2006 dan perencanaannya melalui Permenkes nomor 44 tahun 2016, dengan acuan standar layanan dan sumberdaya yaitu Permenkes 75 tahun 2014.

Permenkes 21 tahun 2016 sebagai kebijakan yang dibahas pada penelitian ini, didasari oleh Pencasila sila ke-5, yang mengamanatkan perlindungan keadilan sosial bagi seluruh rakyat Indonesia serta kaidah konstitusi Bangsa Indonesia yaitu UUD NKRI tahun 1945, pasal $28 \mathrm{H}$ ayat 1sampai 3 serta pasal 34 ayat 1 sampai 3. Kaidah abstraknya adalah UU RI Nomor 40 Tahun 2004 Tentang Sistem Jaminan Sosial Nasional (SJSN) Pasal 24 ayat 2. Sedangkan kaidah konkritnya adalah Peraturan Presiden Republik Indonesia Nomor 12 Tahun 2013 tentang Jaminan Kesehatan, dalam pasal 39 ayat 1 disebutkan bahwa BPJS Kesehatan melakukan pembayaran kepada FKTP secara praupaya berdasarkan kapitasi atas jumlah peserta yang terdaftar di FKTP.

Peraturan Presiden RI nomor 32 tahun 2014, mengatur dana kapitasi FKTP Puskesmas sekurangkurangnya $60 \%$ untuk jasa pelayanan dan sisanya untuk dukungan operasional lainnya. Kemudian terbit Permenkes 19 tahun 2014, yang direvisi oleh Permenkes 21 tahun 2016 tentang Penggunaan Dana Kapitasi Jaminan Kesehatan Nasional Untuk Jasa Pelayanan Kesehatan Dan Dukungan Biaya Operasional Pada FKTP Milik Pemerintah Daerah.

Karena distribusi penyakit dan biaya pengobatan sebagian besar penyakit tidak bervariasi besar, pembayaran dokter/dokter gigi primer layak dilakukan dengan cara kapitasi, atau bayar borongan (Thabrany, 2014). Konsil Kedokteran Indonesia (KKI) menyebutkan jumlah dokter yang tercatat sampai dengan Maret 2017 adalah: jumlah dokter umum: 118.173, dokter gigi: 28.710, dokter spesialis: 32.947 dan dokter gigi spesialis: 3.178 orang. Jumlah keseluruhan dokter dan dokter gigi menjadi 183.008 orang (KKI, 2017).

Kesimpulan evaluasi JKN tahun 2015, Rasio dokter per peserta 1:6.708 peserta (lebih dari rasio ideal sebesar 1 : 5.000 peserta) (P2JK, 2015). Sebagai perbandingan, pada penelitian di India, tahun 2013 rasio dokter dengan penduduk sudah mencapai 1:1.800 penduduk (Deo, 2013). Evaluasi juga menyebutkan bahwa peserta yang terdaftar di setiap FKTP serta besaran rentang kapitasi

Tabel 1. Aspek Temuan Investigasi KPK Dalam Pemanfaatan Dana Kapitasi oleh FKTP Puskesmas tahun 2014

\begin{tabular}{|c|c|c|c|}
\hline REGULASI & PEMBIAYAAN & TATA LAKSANA DAN SUMBER DAYA & PENGAWASAN \\
\hline $\begin{array}{l}\text { 1. Aturan pembagian } \\
\text { jasa medis dan biaya } \\
\text { operasional berpotensi } \\
\text { menimbulkan moral } \\
\text { hazard dan ketidak } \\
\text { wajaran } \\
\text { 2. Belum mengatur } \\
\text { mekanisme } \\
\text { pengelolaan sisa lebih } \\
\text { 3. Aturan kurang } \\
\text { mengakomodasi } \\
\text { kebutuhan } \\
\text { Puskesmas. }\end{array}$ & $\begin{array}{l}\text { 1. Potensi fraud atas } \\
\text { diperbolehkannya } \\
\text { perpindahan } \\
\text { peserta Penerima } \\
\text { Bantuan luran } \\
\text { (PBI) dari } \\
\text { puskesmas ke } \\
\text { FKTP swasta } \\
\text { 2. perubahan } \\
\text { kualitas layanan } \\
\text { puskesmas secara } \\
\text { keseluruhan } \\
\text { belum terlihat } \\
\text { secara nyata. }\end{array}$ & $\begin{array}{l}\text { 1. Lemahnya pemahaman dan } \\
\text { kompetensi petugas kesehatan } \\
\text { dalam menjalankan regulasi } \\
\text { 2. Proses verifikasi eligibilitas } \\
\text { kepesertaan di FKTP belum berjalan } \\
\text { dengan baik } \\
\text { 3. Pelaksanaan mekanisme rujukan } \\
\text { berjenjang belum berjalan baik } \\
\text { 4. Potensi petugas FKTP menjadi } \\
\text { pelaku penyimpangan (fraud) } \\
\text { 5. Petugas puskesmas rentan menjadi } \\
\text { korban pemerasan berbagai pihak } \\
\text { 6. Sebaran tenaga kesehatan yang } \\
\text { tidak merata. }\end{array}$ & $\begin{array}{l}\text { 1. Tidak adanya } \\
\text { anggaran } \\
\text { pengawasan } \\
\text { dana kapitasi di } \\
\text { daerah. } \\
\text { 2. Tidak adanya } \\
\text { alat pengawasan } \\
\text { dan } \\
\text { pengendalian } \\
\text { dana kapitasi } \\
\text { oleh BPJS } \\
\text { Kesehatan }\end{array}$ \\
\hline
\end{tabular}

Tabel 2. Distribusi Dana Kapitasi JKN di Kabupaten Bogor tahun 2015

\begin{tabular}{llrrrr}
\hline & \multicolumn{1}{c}{ No } & \multicolumn{1}{c}{ Mrainimal } & Maksimal & \multicolumn{1}{c}{ Mean } & SD \\
\hline 1 & Pendapatan (ribu) & 213,993 & $3,033,108$ & $1,153,102$ & 608,973 \\
2 & Tarif Kapitasi & 4,500 & 6,000 & 5,347 & 674 \\
3 & Jumlah Peserta & 4,057 & 42,454 & 18,188 & 8,406 \\
4 & Jumlah Dokter & 1 & 6 & 2.68 & 1.39 \\
5 & rasio_dr_peserta & 1,819 & 26,911 & 8,442 & 5,345 \\
\hline
\end{tabular}


yang diterima oleh FKTP Puskesmas pada daerah terpencil / sulit sama dengan daerah perkotaan.

Pada akhir tahun 2014, Komisi Pemberantasan Korupsi (KPK, 2015) melakukan investigas ke beberapa puskesmas, hasilnya sebagai berikut :

Tabel di bawah menunjukkan kondisi penggunaan dana kapitasi di Kabupaten Bogor tahun 2015 sangat bervariasi dan memiliki disparitas tinggi, mulai dari jumlah pendapatan, tariff kapitasi, jumlah peserta, jumlah dokter maupun rasio peserta dengan dokter.

Penelitian dilakukan di Kabupaten Bogor karena cukup terjangkau oleh peneliti sehingga akses untuk mendapatkan data dan evidence lebih mudah, efektif dan efisien, memiliki FKTP Puskesmas terbanyak di Indonesia yaitu 101 FKTP Puskesmas (Kemenkes, 2015), jumlah penduduk 5.111.769 jiwa pada tengah tahun 2015 dan sebanyak $43,82 \%$ penduduknya atau sebesar 2.239.882 jiwa terdaftar sebagai peserta BPJS. Melihat data diatas, peneliti ingin menganalisis bagaimana implementasi kebijakan pemanfaatan dana kapitasi di Kabupaten Bogor tahun 2016 mengenai jumlah dan mekanisme penerimaan dana kapitasi, situasi anggaran dan pemanfaatan dana dan kesesuaian penggunaan dana kapitasi oleh FKTP Puskesmas di Kabupaten Bogor

Diharapkan penelitian ini bermanfaat bagi ilmu pengetahuan untuk membuka wawasan baru, berkembangnya ilmu pengetahuan khususnya mengenai pembiayaan kesehatan di FKTP Puskesmas terutama pemanfaatan dana kapitasi JKN.

\section{Tinjauan Teoritis}

Kata "jaminan", secara bahasa dapat berarti asuransi (insurance), peyakinan (assurance), garansi (guarantee/warranty), janji (promise/ pledge), dan dapat berarti pengamanan (security). Kata "jaminan" yang berarti asuransi di Indonesia berakar dari proses pengumpulan dana bersama untuk kepentingan bersama yang memiliki arti transfer risiko. (Thabrany, 2014). Jaminan menyeluruh melalui jaminan kesehatan dapat didefinisikan sebagai akses terhadap fisik dan keuangan dalam rangka peningkatan kualitas terbaik terhadap pelayanan kesehatan menyeluruh bagi masyarakat. (Kutzin, 2000).

Cakupan universal yang didefinisikan sebagai akses ke intervensi kesehatan berupa promotif, preventif, kuratif dan rehabilitatif untuk semua dengan biaya yang terjangkau, sehingga mencapai kesetaraan dalam akses. Prinsip perlindungan-risiko keuangan memastikan bahwa biaya perawatan tidak menempatkan orang pada risiko bencana keuangan (Stuckler, Feigl, Basu, \& McKee, 2010).

Pada gambar di atas, sumbu populasi mewakili populasi, orang-orang yang membutuhkan pelayanan kesehatan. Layanan axis menggambarkan pelayanan kesehatan yang berkualitas. Sumbu vertikal adalah total biaya, meyakinkan semua penduduk memperoleh semua layanan yang mereka butuhkan. (WHO, 2013).

Menurut Permenkes RI no 59 tahun 2014, tarif kapitasi adalah besaran pembayaran per bulan yang dibayar di muka oleh BPJS Kesehatan

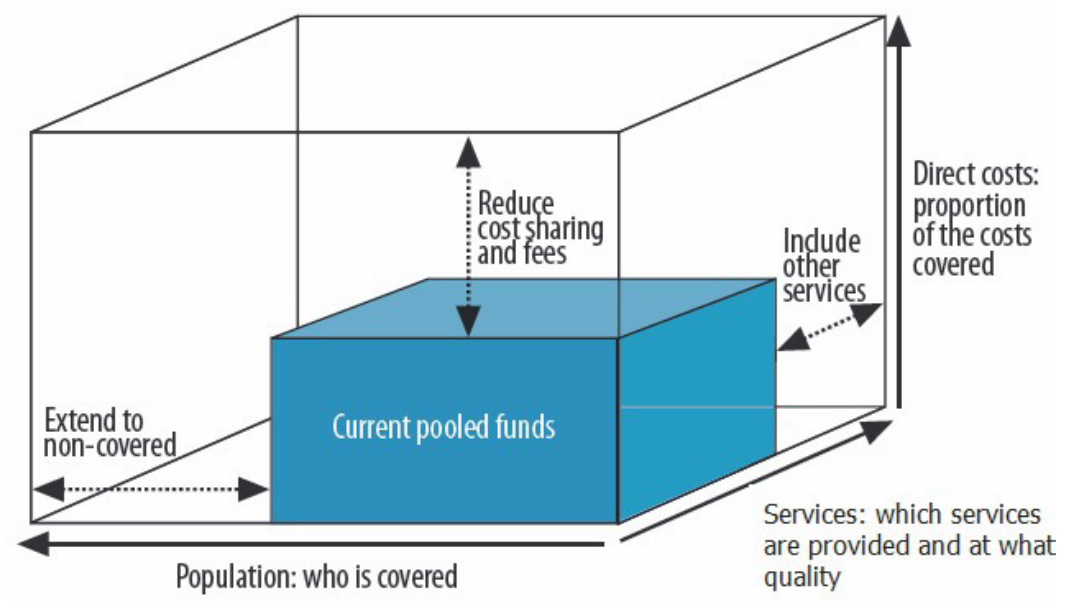

Gambar 1. Skema Jaminan Kesehatan Universal Menurut WHO, 2010 
kepada FKTP berdasarkan jumlah peserta yang terdaftar tanpa memperhitungkan jenis dan jumlah pelayanan kesehatan yang diberikan. Puskesmas layak dibayar dengan cara kapitasi disebabkan pusksmas melakukan administrasi pelayanan; pelayanan promotif dan preventif; pemeriksaan, pengobatan dan konsultasi medis; tindakan medis non spesialistik, baik operatif maupun non operatif; pelayanan obat dan bahan medis pakai habis, termasuk pil dan kondom untuk pelayanan Keluarga Berencana; dan pemeriksaan penunjang diagnostik laboratorium tingkat pertama. (Kemenkes, 2014).

Sedangkan (Alguire, 2016) menyatakan bahwa kapitasi adalah jumlah uang yang tetap per pasien per unit waktu dibayar di muka untuk dokter untuk pemberian pelayanan kesehatan. Jumlah aktual uang yang dibayarkan ditentukan oleh rentang layanan yang disediakan, jumlah pasien yang terlibat, dan periode waktu di mana jasa tersebut diberikan. Tarif kapitasi dikembangkan menggunakan biaya lokal dan pemanfaatan rata-rata layanan dan karena itu dapat bervariasi dari satu wilayah negara lain.

Tarif kapitasi di Indonesia ditentukan berdasarkan seleksi dan kredensial oleh BPJS Kesehatan dan Dinas Kesehatan Kabupaten / Kota dengan mempertimbangkan sumbedaya manusia, kelengkapan sarana dan prasarana, lingkup pelayanan dan komitment pelayanan. Besarana tarif kapitasi yang ditetapkan untuk FKTP Puskesmas atau fasilitas pelayanan kesehatan yang setara adalah sebesar Rp. 3.000,- sampai dengan Rp. 6.000,-.

Menurut (Alguire, 2016), sebagian besar rencana pembayaran kapitasi untuk layanan perawatan primer adalah Pencegahan, diagnostik, dan pengobatan, Suntikan, imunisasi, dan obatobatan diberikan di kantor, Tes laboratorium Rawat Jalan dilakukan baik di kantor atau di laboratorium yang ditunjuk dan Pelayanan pendidikan kesehatan

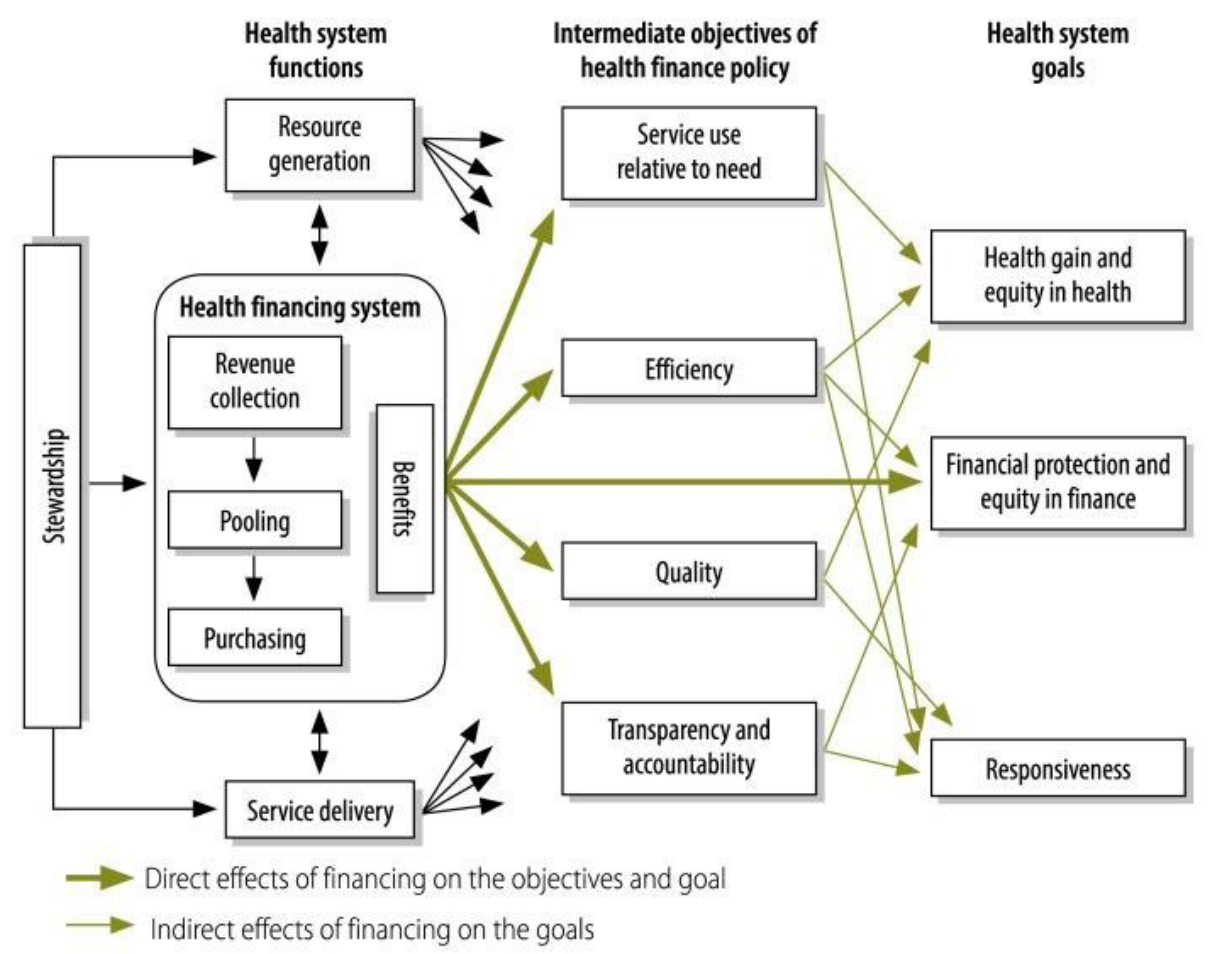

Gambar 3. Tujuan sistem kesehatan dan tujuan kebijakan pembiayaan kesehatan Kerangka konsep diadopsi dari model yang dikembangkan oleh Kutzin (2013), dengan sistem pembiayaan meliputi 3 komponen pokok yaitu pengumpulan dana (revenue collection), pengepulan dana (pooling) dan pembayaran (purchasing) khusus kepada FKTP milik pemerintah yaitu puskesmas. Beberapa aspek yang akan dikaji dari dana kapitasi yang terkumpul di FKTP tersebut meliputi alokasi/perolehan dana kapitasi dari BPJS, penggunaan (utilization) dana kapitasi oleh FKTP dan kesesuaian antara perolehan dana dengan penggunaannya. 


\section{Fungsi Pembiayaan Kapitasi}

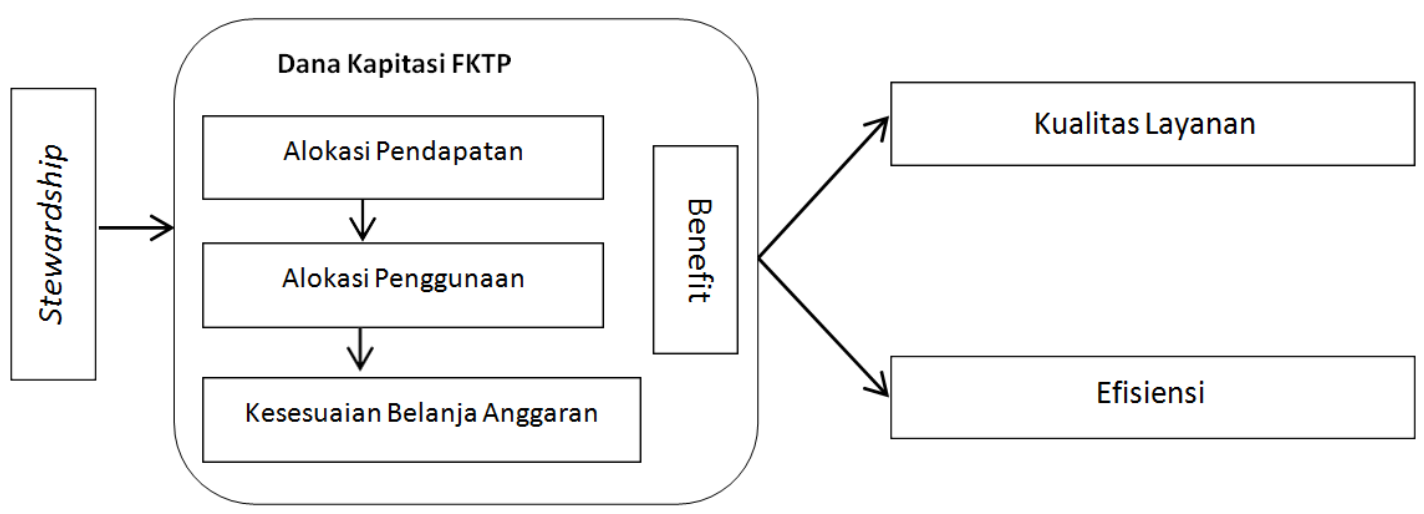

Gambar 4. Kerangka Konsep Pemanfaatan Dana Kapitasi FKTP Puskesmas dimodifikasi dari Kutzin, 2013 yang diadopsi dari WHO 2010

dan konseling dilakukan di kantor. Menurut Permenkes 21 tahun 2016, dana kapitasi pada FKTP milik pemerintah Daerah non BLUD dapat dipergunakan sekurang-kurangnya 60\% untuk pembayaran jasa pelayanan dan sisanya untuk dukungan operasional lainnya yang dialokasikan untuk pengadaan obat, alat kesehatan dan bahan medis pakai habis dan biaya operasional pelayanan kesehatan lainnya yang bersifat upaya kesehatan perorangan.

Sistem pembiayaan kesehatan di pengaruhi oleh beberapa fungsi yaitu pengurusan dan pengawasan oleh pemerintah/pimpinan, sumberdaya fisik dan manusia, pelayanan kesehatan dan pembiayaan. Secara spesifik pada fungsi sistem pembiayaan kesehatan, mencakup pengumpulan pendapatan, penggabungan dalam anggaran dan belanja anggaran yang secara langsung bermanfaat untuk pelayanan sesuai dengan kebutuhan, efisiensi, kualitas serta transparansi dan akuntabilitas (Kutzin, 2013).

Sistem kesehatan dan kebijakan pembiayaan mempunyai tujuan antara dan tujuan akhir sebagai berikut :

Metode

Penelitian ini merupakan penelitian dengan metode kualitatif dengan desain Rapid Assessment Procedure (RAP) dilakukan pada bulan Mei sampai dengan Juni 2017. Informan didapatkan dengan teknik non-probabilitas (purposive), dengan prinsip kesesuaian (appropriateness) berdasarkan pengetahuan atau pengalaman yang dimiliki oleh informan dan prinsip kecukupan (adequacy) dimana informan yang dipilih memenuhi kategori yang berkaitan dengan topik penelitian dan wawancara dilakukan oleh peneliti sampai tidak ada lagi informasi yang baru yang didapat (saturated). key informan dalam penelitian ini adalah 4 orang pejabat dan staf di Dinas Kesehatan, kepala FKTP Puskesmas dan 1 orang dokter pelaksana di 2 FKTP Puskesmas dan pejabat di stakeholder lainnya meliputi pejabat di Bappeda, BPS, BPJS dan Dinas Sosial Kabupaten Bogor.

Pengumpulan data primer berasal dari wawancara mendalam, sedangkan sekunder dikumpulkan dengan melakukan telaahan terhadap dokumen yang berhubungan dengan kebijakan pemanfaatan dana kapitasi JKN pada FKTP Puskesmas. Pengumpulan data awal dilakukan dengan wawancara dengan pejabat Dinas Kesehatan dan pengumpulan literatur.

Analisa data melalui analisa isi (content analysis) dengan metode triangulasi diakukan untuk validitas data, meliputi triangulasi sumber dan triangulasi metode. Pengumpulan data dilakukan setelah keluar surat lolos kaji etik dan dimulai dengan memberikan penjelasan pada informan yang identitasnya disamarkan serta dilakukan prosedur pengamanan data hasil penelitian.

\section{Hasil}

Data dana kapitasi pada FKTP Puskesmas di Kabupaten Bogor tahun 2016 menunjukkan variasi cukup besar dengan standar deviasi sebesar Rp. 660,4 juta. Norma kapitasi bervariasi yaitu berkisar antara Rp 4.500 sampai dengan Rp. 6.000, dengan jumlah peserta sangat bervariasi dengan standar 
deviasi sebesar 7.952 peserta. Rasio dokter terhadap peserta juga memiliki variasi yang cukup besar, dengan standar deviasi satu orang dokter untuk 6.426 peserta, dengan rata-rata 6.765 peserta untuk 1 orang dokter.

Besaran dana kapitasi JKN pada FKTP Puskesmas didapatkan dari jumlah peserta dikalikan dengan norma kapitasi perbulan di puskesmas. Terkait kepesertaan, datakepesertaan masih banyak yang belum valid sehingga harus dilakukan verifikasi. Di tingkat kabupaten, verifikasi dilakukan oleh Dinas Sosial dengan data dasar dari Dinas Kependudukan dan Catatan Sipil. Masalah lainnya yaitu jumlah peserta yang sangat tidak merata antar FKTP Puskesmas dan jumlah dan sebaran dokter tidak merata.

“... Dinas Sosial itu, mereka yang setiap saat mendapatkkan data dari desa, yah... " (1) "rasio dokter peserta hanya 1 per 1000 an di tempat lain 26.000 .. " (3)

"Makaya di tiap puskesma tidak sama, ada jumlah peserta dia 32.000 , ada yang 16.000 ada 10.000 ada 8.000 “(9)

Terkait dengan tarif kapitasi, kondisi menunjukkan disparitas antar puskesmas yang menunjukkan kualitas dan kuantitas sumber daya di puskesmas yang berbeda.

Jadi kita inginnya, kalo semua di puskesmas standar, maka kapitasi yang diterima juga akan sama, saat ini masih ada ketimpangan" (1)

“...apa kekurangan SDM, apa kekurangan alat atau apakah ada hitungannya itu kenapa dia dapat kapitasinya per orang 4.500 ... “ (12)

Pada tahap awal perencanaan, beberapa puskesmas telah melakukan proses perencanaan melalui analisis kebutuhan mengacu kepada Permenkes 44 tahun 2016 tentang Manajemen Puskesmas, namun belum semua puskesmas melakukannya sesuai dengan pedoman ini.

“...mapping kegiatan ..., dasarnya dari tahun kemarin. Mereka bikin anggaran per bidang per program...kegiatan utama... pengembangan butuhnya berapa anggarannya. Sumbernya itu nanti, yang penting berapa total anggaran, baru setelah itu diplot dari mana sumber anggarannya." (2)

"tidak semua puskesms melakukan analisis, kadang-kadang ada mereka langsung membuat RKA..." (4)

Dalam penganggaran jasa pelayanan, gap besaran jasa pelayanan yang diterima, terjadi baik antar FKTP Puskesmas, maupun internal puskesmas itu sendiri. Selain itu, penentuan point daerah dalam menentukan jaspel terkendala oleh perbedaan persepsi antar puskesmas.

“..adanya gap tinggi banget... terendah mungkin dilevelan 1 juta rupiah, di banding dengan misalnya dokter bisa $1000 \%$ perbedaannya." (5)

“...dokter dengan yang perawat di wilayah lain sama..." (7)

“...kewenangan daripada Kepala Puskesmas kita menambahkan porsi daerah / Point daerah yang kita SK kan, ada SK nya" (4)

“ tidak ada kewenangan kepala FKTP untuk memberikan reward ...punishment... " (5)

Penganggaran dana kapitasi pada porsi $40 \%$, untuk puskesmas dengan kapitasi kecil sulit dalam penganggaran karena dananya kecil. Namun pada puskesmas dengan dana kapitasi besar, kesulitan menentukan kegiatan ketika anggaran kapitasi bertambah besar. Kesulitan puskesmas lainnya adalah dalam penganggaran kegiatan promotif dan preventif yang dapat overlap dengan kegiatan bersumberdana Bantuan Operasional Kesehatan (BOK), meski dapat juga saling melengkapi.

"Tapi di jasinga ini Alhamdulillah dilengkapi dengan dana operasional dan BOK untuk sementara ini cukup.." (5)

"Sekarang banyak overlapping karena JKN sekarang boleh promotif preventif. " (5) "Kan dari kapitasi gak ada buat operasional ke lapangan" (7)

“...sekarang sudah terpenuhi... harusnya sudah mulai ada mutasi,perubahan persentase anggaran ... Mungkin setiap lima tahun harus ada evaluasi mendasar" (5)

“...kalo dari segi pengadaan barang sih, pasti numpuk-numpuk terus. Misal di kita mungkin 2 sampai 3 tahun ke depan semua terpenuhi." (6)

Prinsip efisiensi dalam penggunaan dana kapitasi sangat penting, agar dengan dana yang tersedia, puskesmas mampu memenuhi kuantitas dan kualitas yang maksimal dalam memenuhi kebutuhannya.

\footnotetext{
" Barang yang diadakan puskesmas harus yang berkualitas, kegiatan juga." (2) “... jangan karena gengsi dan kebutuhan yang tidak perlu " (5)

"Efisien iya, tapi tidak mampu memenuhi kebutuhan kami dalam memberikan pelayanan." (7)

Saat ini, pemanfaatan fasilitas pelayanan kesehatan di Puskesmas oleh peserta BPJS masih
} 
cukup kecil, terutama di daerah perkotaan. Hal ini berbeda pada daerah rural, masyarakat yang memanfaatkan pelayanan kesehatan cukup tinggi. Selain pemanfaatan, angka rujukan puskesmas juga masih cukup tinggi.

“kunjungan peserta JKN itu tidak melebihi 5\%... 15\%, akses yang bagus. “ (3) "... selama ini imagenya faskes swasta lebih bagus dimata masyarakat” (3)

"mereka yang punya BPJS pun... yang PBI... enggak mau datang ke puskesmas..." (7)

"Masyarakat sudah terimage bahwa, saya sudah terbiasa ke rumah sakit. Jadi kalo diatur dengan sistem rujukan berjenjang, masih reject" (1)

“Masalah rujukan... orang malas masukan ke aplikasi Pcare..., kurangnya pemahaman masyarakat... pasien nya rewel,... RS yang rewel minta lagi rujukan." (6)

Yang paling berefek pada pemanfaatan dana kapitasi adalah peningkatan performance puskesmas, terutama pada puskesmas dengan dana kapitasi besar, meski pada puskesmas dengan dana kapitasi kecil tetap sulit.

"Masyarakat merasakan pelayanan berbeda dulu dengan sekarang. " (2)

“...puskesams sekarang sudah bagus bagus, sarana juga udah banyak yang terpenuhi kemudian pelayanannya juga sudah ada peningkatan gitu" (4)

“Disini gak ada ya. Untuk packaging luarnya, untuk seluruhnya pun tidak ada, dana kita terbatas. Paling jaspel aja ya" (8)

Masalah terkait dengan sumberdaya aparatur, baik kualitas dan kuantitas diantaranya yaitu terbatasnya jumlah dan sebaran dokter serta upaya peningkatan kapasitas bersumber dana kapitasi masih belum maksimal meski jumlah pelatihan bertambah, terutama pada puskesmas dengan dana kapitasi kecil. Jumlah dokter yang terbatas disbanding peserta JKN menyebabkan rasio dokter dengan peserta pun tinggi, hal ini tentu dapat menurunkan kualitas layanan karena dokter memeriksa pasien melebih kemampuannnya, hal sebaliknya pada puskesmas dengan rasio dokter dengan peserta kecil, dokter memiliki waktu banyak untuk memeriksa pasien.

"Cuma karena biaya nya lumayan besar, untuk pelatihan-pelatihan itu, kita kurang dananya...2016, kita malah cuma satu pelatihan" (7)

“Jadi kalo misalnya di satu puskesmas..., rasio dokter peserta hanya 1 per 1000 an di tempat lain
26.000 jelas dampaknya pada kualitas pelayanan pada peserta. " $(3)$

Terhendel, terhendel, cuman kualitasnya jelek, jujur saja, karena saya tidak bisa lebih teliti dalam memeriksa" (6)

Terus terang di sentul ini, masyarakatnya, terutama pendidikan kesehatannya masih kurang sekali, jadi kita mendapatkan kesempatan juga untuk memberikankesempatan arahan untuk supaya lebih sehat." (8)

Pemanfaatan dana kapitasi untuk obat-obatan di puskesmas tahun 2016 tidak berjalan dengan baik karena kendala di pengadaan. Hal ini terjadi pada puskesams dengan dana kapitasi yang besar maupun kecil. Kekurangan obat mengakibatkan pemberian obat oleh dokter menjadi kurang rasional

“...e-katalog, saya pengadaan obat 380 jutaan, tapi realiasasi hanya 20 juta. “ (5)

... satu, ... masih baru dalam pengadaan online. Kedua keterbatasan stok di online, yang ketiga, ketersediaan obat ... Yang keempat... pengaturan persen untuk obat"' (6)

"Ya sudah kita kurangi obatnya yang harusnya misalnya harusnya untuk 3 hari kita potong jadi dua hari, jadi satu hari... Yang kedua kita lakukan substitusi... kita potong saving dari pemerintah, dari pemerintah tidak ada ya kita ambil dari kapitasi... terakhir ya menyarankan pasien untuk beli sendiri... " (6)

"Kalo untuk obat, untuk yang 2016 kemarin kita malah kurang... dan itu ditenderkan dari dinasnya itu lambat turun.." (7)

“... kita kasih dulu segini, nanti ibu balik lagi ya berapa hari... kita cek lagi. " (7)

"Sangat tidak rasional pak, misal kita resepkan antibiotic amoksisilin sehari 3 kali, mau tidak mau jadi sehari 2 kali. “(8)

Terbatasnya dana kapitasi pada puskesmas dengan peserta JKN sedikit, menyebabkan puskesmas tidak mampu melengkapi sarana yang penting di Puskesmas, misalnya laboratorium. Akibatnya, puskesmas tersebut merujuk pemeriksaan laboratorium ke puskesmas lain, bahkan ke puskesmas di bawahnya yang dana kapitasinya lebih besar.

"di sentul ini kebetulan banyak yang belum terpenuhi, seperti Lab, kita belum, kita gak punya lab..." (7)

"si pasien dilayani dengan baik, kalaupun tidak ada lab, puskesams wajib merujuk lab ke puskesmas lain" (9) 
Pemanfaatan dana kapitasi untuk pengadaan alat penunjang lainnya terutama untuk puskesmas dengan dana kapitasi besar, sebagian besar kebutuhan mereka sudah terpenuhi, seperti komputer, AC, TV, kursi meja rapat dan sebagainya. Bahkan seluruh ruangan mereka sudah terpasang $\mathrm{AC}$.

"Jadi untuk jasinga, semua ruangan sudah ada
computer, sudah terkoneksi dengan LAN, termasuk
dengan e puskesmas, sudah terkoneksi dengan
dinas" (5)

"AC pun sudah cukup semua ruangan saya pasang, cuma masalahanya, kita pasang AC listrik tidak kuat" (5)

"Secara umum kursi, meja rapat, dll sekarang sudah dipenuhi. Sekarang saya tinggal dipercantik, missal ruang aula nanti pake wallpaper." (5)

Pada upaya promotif dan preventif, upaya yang dilakukan adalah penyelenggaraan keluarga sehat, kunjungan sehat, kelompok lansia, kelompok risiko. Kegiatan dalam gedung dan luar gedung dapat dibiayai oleh dana JKN, meski pada puskesmas dengan dana kapitasi kecil tetap sulit. Namun kegiatan-kegiatan ini belum terlihat berdampak terhadap capaian indikator kesehatan masyarakat.

\begin{abstract}
"Yang permenkes 21 kan lebih kea rah UKM nya, dulu kan UKP tok." (2)

"BPJS sudah merasakan bahwa klaim dari rumah sakit semakin besar, itu karena UKM nya gak jalan. “( 2 )

“... target capaianya itu nggak terlalu signifikan ya dengan uang yang banyak itu" (4)

“ kegiatan untuk kuratif seperti home visit kasus kusta, TB paru, filariasis, dll, demam berdarah, kita semua bisa masukkan ke JKN, khususnya untuk kegiatan transportnya. Untuk pertemuan, rakor misalnya saya ada rakor tentang $D B D$, rakor tentang KIA,
\end{abstract}

rakor tentang TB Paru, HIV,AIDS, dll, yang tadinya di BOK sekarang saya masukkin ke JKN" (5)

Berdasarkan uraian kesesuaian pemanfaatan dana kapitasi diatas, meskipun belum pernah dilakukan survei kepuasan masyarakat di tingkat Kabupaten, namun beberapa puskesmas telah melakukan survei kepuasan yang hasilnya cukup memuaskan.

"survey kepuasan itu kan di puskesmas, tapi kita ga pernah tahu apakah...masyarakat itu puas dengan pelayanan di Puskesmas..." (4)

\author{
"survey kepuasan pelanggan sederhana kami \\ memperlihatkan $87,3 \%$ puas, nah ini 13 \\ \% yang jadi penyakit..." (5)
}

Sistem pengelolaan anggaran di Pukesmas yang mengacu pada pengelolaan keuangan daerah secara umum, dengan porsi anggaran mengikuti Permenkes 21 tahun 2016, mengakibatkan puskesmas tidak fleksibel dalam pelaksanaanya. Hasil wawancara menunjukkan jalan keluarnya adalah penerapakan Pola Pengelolaan Keuangan Badan Layanan Umum Daerah (PPK-BLUD). Dengan PPK-BLUD puskesmas akan lebih fleksibel, bertanggungjawab, inovatif dan lebih leluasa dalam pengelolaan anggaran serta dapat mengangkat pegawai sendiri, sehingga kekurangan dokter dapat teratasi.

\footnotetext{
" lebih fleksibel memanfaatkan dan dia memiliki tanggungjawab yang lebih besar” (1) “...dengan BLUD, dia bisa berinovasi untuk lebih meningkat lagi"' (1)

"Sehingga lebih leluasa dalam pengelolaan keuangan, gitu... " (3)

"Di BLUD kan bisa ada flkesibilitas, karena bisa... pengadaan sendiri." (5)

“...puskesmas bisa rekrut dokter sendiri, kesulitan tenaga dokter supaya rasio dokter dengan peserta itu bisa berkurang ya" (7)
}

\section{Pembahasan}

Disparitas kepesertaan JKN terjadi karena penempatan peserta JKN PBI sesuai dengan wilayah tempat tinggalnya serta sebaran penduduk miskin yang menjadi peserta PBI yang persentasenya tidak merata. Hal ini sesuai dengan hasil evaluasi Kementerian Kesehatantahun 2015, bahwa peserta JKN yang terdaftar pada FKTP Puskesmas belum ideal. Rasio dokter dengan peserta JKN sebesar 1: 6.765, masih lebih tinggi dari standar nasional sebesar 1:5.000 peserta, bahkan masih lebih besar dari rata-rata nasional yaitu sebesar 1: 6.708 peserta. Maksimum rasio dokter per peserta JKN di Kabupaten Bogor mencapai 1:30.006 peserta.

Tingginya rasio peserta berakibat pada penurunan kualitas waktu pelayanan. Angka 1:5.000 didapatkan bila 1 orang dokter melayani pasien selama 10 menit per pasien, dengan pemeriksaan selama 5 jam dan 25 hari kerja (MKEKI, 2002), maka bila lamanya dokter memeriksakan setiap pasien yang berkunjung idealnya 15 - 20 menit (Linzer et al., 2015) atau 18 - 20,9 menit (Abbo, Zhang, Zelder, \& Huang, 2008), bila diambil 20 menit saja dengan kunjungan peserta 15\%, maka 
Tabel 3. perbedaan pemanfaatan dana kapitasi pada puskesmas dengan dana kapitasi besar dan kecil

\begin{tabular}{ll}
\hline \multicolumn{1}{c}{ KAPITASI BESAR } & KAPITASI KECIL \\
\hline Kuantitas terpenuhi, kualitas dalam proses & Kuantitas dan kualitas tidak terpenuhi \\
\hline Pemanfaatan oleh masyarakat tinggi & Pemanfaatan oleh masyarakat rendah \\
\hline Kualitas pencatatan pelaporan rendah & Kualitas pencatatan pelaporan lebih baik \\
\hline Performance keseluruhan meningkat & Performance tidak ada peningkatan \\
\hline Pengadaan Pelatihan masih rendah & Pengadaan pelatihan SDM tidak ada \\
\hline Kualitas pemeriksaan dokter 'terpaksa' diturunkan, & Kualitas pemeriksaan dokter terjaga, kuantitas \\
\hline kuantitas banyak. & sedikit. \\
\hline Blkes/medis pakai cukup & Alkes/medis pakai terbatas, tidak mampu \\
& mengadakan Lab. \\
\hline $\begin{array}{l}\text { Dana kapitasi membiayai UKM (perjalanan, } \\
\text { pertemuan, dll) }\end{array}$ & Barang penunjang kantor/rumah tangga sangat \\
\hline
\end{tabular}

idealnya rasio dokter dengan peserta maksimum sebesar $1: 2.500$ peserta.

Dengan rata-rata rasio dokter dengan peserta 1:6.765 peserta, bila standar kunjungan $15 \%$ dari peserta dan jam kerja dokter 5 jam per hari serta 25 hari kerja, maka waktu pemeriksaan dokter terhadap pasien rata-rata hanya sekitar 7,4 menit per pasien dibawah standar waktu pemeriksaan. Bahkan pada puskesmas yang rasionya tinggi, waktu pemeriksaan akan semakin lebih singkat. Pada rasio maksimal 1:30.006 dokter per peserta dengan standar kunjungan dan jam kerja dokter yang sama, maka waktu pemeriksaan per pasien hanya sebesar 1,67 menit. Waktu pemeriksaan yang semakin singkat ini, tentu akan menurunkan kualitas pelayanan dokter. Belum lagi jika ditambah dengan pasien non peserta JKN, tentu akan semakin berat lagi.

Pemanfaatan dana kapitasi masih terkendala dengan banyaknya puskesmas yang tidak melakukan proses perencanaan sesuai dengan mekanisme pada aturan yang berlaku yaitu Permenkes 44 tahun 2016. Kendala yang dihadapi oleh pusksemas adalah terbatasnya sumberdaya yang memahami perencanaan, komitment yang rendah dari kepala dan personil puskesmas terhadap perencanaan, belum maksimalnya dukungan pembinaan dari Dinas Kesehatan dan tidak adanya petunjuk pelaksanaan yang aplikatif di puskesmas. Secara teknis, hambatan dalam penyusunan perencanaan anggaran dana kapitasi yaitu adanya peruntukkan yang sama dari dua sumber anggaran yaitu kapitasi JKN dan BOK yang dapat membiayai upaya promotif dan preventif yang dapat menimbulkan potensi overlapping alokasi dana. Hambatan lain yang ada yaitu dana kapitasi yang terbatas, potensi sisa anggaran menumpuk dan regulasi yang ada tidak memungkinkan untuk mengalihkan porsi anggaran.

Pada kesesuaian pemanfaatan dana kapitasi, terdapat perbedaan yang cukup jauh antara puskesmas dengan dana kapitasi besar dengan dana kapitasi kecil, seperti yang dapat dilihat pada tabel berikut :

Tabel diatas menunjukkan bahwa kesesuaian pemanfaatan dana kapitasi dengan hasil yang dicapai berbeda antara puskesmas dengan dana kapitasi besar dan puskesmas dengan dana kapitasi kecil. puskesmas dengan dana kapitasi besar lebih dapat memenuhi tujuan antara kebijakan UHC menurut WHO yaitu kualitas layanan terhadap peserta, namun berisiko aspek efisiensi tidak tercapai bila dalam penganggaran tidak disesuaikan dengan kebutuhan yang sebenarnya sesuai dengan situasi dan kondisi serta kurang memperhatikan kebutuhan masyarakat terhadap layanan kesehatan. Sebaliknya pada puskesmas dengan dana kapitasi kecil, tujuan peningkatan kualitas layanan masih sulit untuk tercapai mengingat anggarannya sangat terbatas. Namun pada puskesmas dengan dana kapitasi kecil ini bisa lebih efisien karena memang dana mereka juga terbatas.

Beberapa hal yang memiliki kesamaan antara puskesmas dengan dana kapitasi besar maupun dana kapitasi kecil, yaitu : angka rujukan tinggi; tidak bisa mengangkat pegawai; obat- obatan kurang karena mekanisme pengadaan online yang belum 
maksimal; kontribusi terhadap capaian indikator rendah dan belum pernah ada survei kepuasan oleh kabupaten ataupun Kementerian Kesehatan.

\section{Kesimpulan}

Puskesmas dengan dana kapitasi besar memiliki keleluasaan lebih dalam pengelolaannya, sedangkan puskesmas dengan dana kapitasi kecil, sangat terbatas. Sejak awal tahun 2014, pertama kali program JKN dilaksanakan sampai dengan saat ini masih banyak permasalahan dari berbagai aspeknya. Masalah muncul bukan hanya pada aspek pendanaan seperti yang menjadi fokus penelitian, namun juga pada masih terbatasnya sumberdaya puskesmas dan rendahnya kualitas layanan kesehatan yang peningkatannya juga sangat diperngaruhi oleh pembiayaan kesehatan.

Pemasalahan sumberdaya yang muncul diantaranya yaitu diisparitas yang tinggi dalam jumlah dan sebaran tenaga kesehatan, khususnya rasio dokter dengan peserta JKN yang menunjukkan dalam proses penempatan tenaga kesehatan yang kurang memperhatikan jumlah penduduk. Rasio dokter dengan peserta yang tinggi berdampak pada waktu pelayanan yang semakin singkat. Selain jumlah dan sebaran tenaga kesehatan, kualitas sumberdaya jugamasih sangat tidak merata. Upaya peningkatan kapasitas sumberdaya aparatur telah dilakukan menggunakan dana kapitasi, namun hasilnya masih belum maksimal terutama pada puskesmas dengan dana kapitasi kecil.

Pemenuhan standar kualifikasi puskesmas mengacu pada Permenkes 75 tahun 2014 banyak terkendala pada puskesmas dengan dana kapitasi kecil karena keterbatasan jumlah dana. Meski demikian, pada puskesmas dengan dana kapitasi besar pun sangat dipengaruhi oleh proses perencanaan awal kegiatan yang banyak diantaranya belum menerapkan proses perencanaan menggunakaan standar Permenkes 44 tahun 2016. Dalam proses pengaanggaran, semua puskesmas telah melaksanakan pembagian porsi anggaran dengan menggunakan Permenkes 21 tahun 2016.

Pemanfaatan dana kapitasi porsi $60 \%$ untuk jasa pelayanan sesuai dengan Permenkes 21 tahun 2016, terkendala pada perbedaan persepsi penentuan point tambahan yang menjadi kewenangan kepala puskesmas. Perbedaan besarnya dana kapitasi yang diterima, menyebabkan perbedaan penerimaan jasa pelayanan antar puseksmas dengan jenis tenaga yang sama. Sementara, pembagian point sesuai dengan
Permenkes 21 ini menimbulkan perbedaan yang sangat besar jasa pelayanan yang di terima di internal puskesmas.

Pemanfaatan dana kapitasi porsi $40 \%$ untuk penunjang operasional lainnya sesuai dengan Permenkes 21 tahun 2016, sangat bervariasi tergantung jumlah dana kapitasi yang diterima oleh puskesmas. Permasalahan yang cukup besar ada pada pengelolaan obat-obatan, yang menurut Permenkes 21, obat berasal dari dana kapitasi dapat dipergunakan oleh seluruh pasien di Puskesmas. Adanya transisi proses pengadaan obat secara online menimbulkan kegagalan pengadaan obat baik pada puskesmas dengan dana kapitasi besar maupun kecil. Hal ini mengakibatkan puskesmas kekurangan obat yang berdampak pada pengobatan pasien yang kurang rasional. Selain pada pengadaan obat, pada puskesmas dengan dana kapitasi kecil tidak mampu mengadakan fasilitas memadai untuk penunjang medik, terutama laboratorium. Dampaknya adalah puskesmas tersebut merujuk pemeriksaan laboratorium ke fasilitas kesehatan lainnya. Pemenuhan fasilitas penunjang lainnya, seperti pemeliharaan sarana prasarana dan pengadaan peralatan kantor dan rumah tangga juga sangat berbeda antara puskesmas dengan dana kapitasi besar dan dana kapitasi kecil yang sangat terbatas.

Pemanfaatan dana kapitasi untuk peningkatan upaya promotif dan preventif dilakukan dengan upaya pelayanan dalam gedung dan luar gedung yang tidak bermasalah pada puskesmas dengan dana kapitasi besar, meski tetap terbatas pada puskesmas dengan dana kapitasi kecil. Namun, upaya promotif dan preventif yang pelaksanaannya terutama didanai oleh sumber dana lain yaitu BOK, menimbulkan kesulitan puskesmas dalam tahap perencanaan awal yang dikhawatirkan overlapping dengan dana kapitasi JKN.

Dua hal penting lainnya terkait masalah pemanfaatan dana kapitasi adalah potensi sisa anggaran menumpuk dan fleskibilitas penggunaan dana. Pada puskesmas dengan dana kapitasi besar, potensi sisa anggaran menumpuk juga akan semakin besar. Bila puskesmas tidak cerdik dan tidak mampu inovatif dalam penganggaran dan pemanfaatan dana maka mereka akan kesulitan dalam mengalokasikan sisa anggaran ini secara tepat, efektif dan efisien. Penyebab lainnya dari sisa dana yang menumpuk adalah kurang fleksibelya penggunaan dana, sehingga puskesmas tidak dapat menyerap anggaran yang 
tidak dapat diserap pada tahun berjalan kepada kebutuhan lainnya. Upaya menggatasi ketidak fleksibel an ini dapat diatasi dengan penerapan PPK-BLUD

\section{Saran}

1. Perlunya segera akselerasi pemenuhan rasio dokter per peserta ideal, dengan didukung oleh regulasi dan langkah-langkah yang konkrit serta mudah dilaksanakan.

2. Penting untuk meningkatkan kembali fungsifungsi perencanaan dalam manajemen puskesmas sesuai dengan regulasi melalui keterlibatan seluruh personil di puskesmas dengan pendampingan dan pembinaan serta petunjuk pelaksanaan yang mudah untuk diaplikasikan di puskesmas. Penting juga melibatkan akademisi khususnya administrasi dan kebijakan kesehatan dalam pengembangan manajemen puskesmas ini.

3. Dapat dipertimbangkan untuk melakukan revisi Permenkes 21 tahun 2016, dengan melewati tahap evaluasi menyeluruh terhadap pemanfaatan dana kapitasi JKN.

4. Perlu komitmen bersama untuk mengatasi ketimpangan pendanaan puskesmas, dengan menutupi kekurangan pendanaan pada puskesmas dengan dana kapitasi kecil, melalui sumber dana lainnya seperti APBD Kabupaten.

5. Perlunya akselerasi penerapan PPK-BLUD di Puskesmas dengan didukung oleh regulasi dari Kementerian Kesehatan yang mengatur tentang PPK-BLUD Puskesmas yang punya kekhususan tersendiri.

\section{Daftar Referensi}

1. Abbo, E. D., Zhang, Q., Zelder, M., \& Huang, E. S. (2008). The Increasing Number of Clinical Items Addressed During the Time of Adult Primary Care Visits. Journal of General Internal Medicine, 23(12), 2058-2065. doi:http://dx.doi. org/10.1007/s11606-008-0805-8

2. Alguire, P. C. (2016). Understanding Capitation. Internal Medicine. Retrieved from https:// www.acponline.org/about-acp/about-internalmedicine/career-paths/residency- careercounseling/understanding-capitation

3. Deo, M. G. (2013). Doctor population ratio for India - The reality. Indian Journal of Medical Research, 137(4), 632-635. Retrieved from http://www.ijmr.org.in/article.asp?issn=09715916; year $=2013$; volume $=137$; issue $=4$; spage $=632$; epage $=635 ;$ aulast $=$ Deo

4. Kemenkes. (2009). Sistem kesehatan nasional: Jakarta.

5. Kemenkes. (2014). Permenkes no. 28 tahun 2014 tentang Pedoman Pelaksanaan Program Jaminan Kesehatan Nasional.

6. Kemenkes. (2015). Jumlah Puskesmas per Juni 2015 menurut Propinsi dan Kabupaten / Kota. Retrieved from http://www.depkes. go.id/download.php?file=download/pusdatin/ lain- lain/JumlahPuskesmas 30 Juni 2015.pdf

7. KPK. (2015). KPK Temukan 4 Kelemahan Pengelolaan Dana Kapitasi. Retrieved from https://www.kpk.go.id/id/berita/siaranpers/2440-kpk-temukan-4-kelemahanpengelolaan-dana-kapitasi

8. Kutzin, J. (2000). Towards universal health care coverage. A goal-oriented framework for policy analysis. Health, Nutrition and Population (HNP) discussion paper. Washington DC: The World Bank.

9. Kutzin, J. (2013). Health financing for universal coverage and health system performance: concepts and implications for policy. Bulletin of the World Health Organization, 91(8), 602-611. doi:10.2471/BLT.12.113985

10. Linzer, M., Bitton, A., Tu, S. P., Plews-Ogan, M., Horowitz, K. R., \& Schwartz, M. D. (2015). The End of the 15-20 Minute Primary Care Visit. Journal of General Internal Medicine, 30(11), 1584-1586. doi:10.1007/s11606-015-3341-3

11. MKEKI, I. (2002). Kode Etik Kedokteran Indonesia dan Pedoman Pelaksanaan Kode Etik Kedokteran Indonesia. Retrieved from http://luk.staff.ugm.ac.id/atur/sehat/Kode-EtikKedokteran.pdf

12. P2JK. (2015). Evaluasi Pengelolaan dana JKN tahun 2015. Retrieved from https://goo. $\mathrm{gl} / \mathrm{O} 4 \mathrm{gVJH}$

13. Stuckler, D., Feigl, A., Basu, S., \& McKee, M. (2010). The political economy of universal health coverage. Background paper for the global symposium on health systems research.

14. Thabrany, H. (2014). Jaminan kesehatan nasional.

15. WHO. (2013). Universal health coverage: supporting country needs. Geneva: World Health Organization. 